\title{
The Migration Crisis and the Impact on the European Union Economic Diplomacy, How to solve it?
}

\author{
Anca Gabriela Ilie and Dan Dumitriu \\ The Academy of Economic Studies, Faculty of International Business and Economics, \\ Bucharest, Romania \\ Correspondence should be addressed to: Anca Gabriela llie; ancaionescu2003@yahoo.com \\ Received date: 27 March 2017; Accepted date: 29 May 2017; Published date: 5 December 2017 \\ Academic Editor: Robert-Adrian Candoi-Savu
}

Copyright (C) 2017. Anca Gabriela Ilie and Dan Dumitriu . Distributed under Creative Commons CC-BY 4.0

\begin{abstract}
This scientific article tries to analyze the impact that the refugee crisis had on the EU's economic diplomacy. The paper shows which is the current state of economic diplomacy, stressing that the issue of mass migration to Europe is not of demographic nature, but of spiritual, cultural and civilizational nature, in other words, it is a crisis of fundamental values on which the European project was built. Based on a scientific methodology based primarily on a qualitative analysis, the authors find that European economic diplomacy must get together with diplomacy refugees, a new form of diplomacy (without a structured framework) which refers to the national frame, European frame and international border control and migration legislation, which is most often exercised not by real diplomats but by ministers or commissioners interested in immigration, internal or external control. Thus, this paper seeks to answer the following questions: To what extent can we talk about a relaxed policy of the European economic diplomacy regarding the management of the refugee crisis? What is the European Union's future after the passage of migratory flows? What is Romania's position?
\end{abstract}

Keywords: Economic Diplomacy, Refugees, Immigrants, Refugee crisis

\section{Introduction}

Since 2015, the European Union is facing the greatest crisis in its history of over 65 years of building policy, based on solidarity, safety and welfare for the countries that accepted the EU membership. The wave of immigrants has had a sudden entry into the EU space raising many questions on the lax policies of the European Union on border security and ensuring the well-being of the European population (be it indigenous or resulting from migration).

Moreover, the refugees' issue caused a shortcircuit in the European space, also bringing a

Cite this Article as: Anca Gabriela Ilie and Dan Dumitriu (2017)," The Migration Crisis and the Impact on the European Union Economic Diplomacy, How to solve it? ", Journal of Eastern Europe Research in Business and Economics, Vol. 2017 (2017), Article ID 562051, DOI: 10.5171/2017. 562051 
special interest in the contemporary diplomatic activity of the EU member states. Refugees or imigrants, as the political leaders and the media prefer to call them, represent a serious challange for the commom European values already tested by the Euro zone crisis, terrorist attacks, the rise in extremist parties or the eventual Brexit.The motivation behind this paper is, foremost, to fill a scientific gap, and because it is an ongoing phenomenon with data that are constantly updating, the Romanian scientific literature suffers from a shortage of coverage of the "refugee crisis" topic.[1]

The fundamental objective of this research is to analyze the implications of the refugee crisis on EU economic diplomacy, particularly on Romania. The research started with the following questions: What is the role of the European economic diplomacy in the current global context? What are the main challenges for the refugee crisis on EU economic diplomacy? What is Romania's attitude and reaction on crisis management?

The literature review used is a balanced one. The analysis is based primarily on primary sources as a basis for speech analysis and a technical analysis of the policy documents adopted by the European Union, complemented by the use of academic sources both national (Sebe M. or Soare S. \& Postelnicu C.) and international (Kaplan or Maley) and analytical resources published by think tanks well-known on a transatlantic level, but also media resources. The analysis on the migration towards Europe and its correlation with the European Union's economic diplomacy represents a brave but also risky approach as it is based on an ongoing phenomenon where information changes daily and that seems to question an entire set of philosophical and political values on which the European project was built [2].

The migration flow that has rocked Europe since 2015 is the sign of a deep administrative and political crisis of the European leadership unable to defend the values that the European project was founded on - united in diversity. One of the secondary hypotheses is that there is a panoply of causes that led to the wave of immigrants, causes that can be classified into the "push-draw" specter. Moreover, if the general feeling in Bucharest related to the refugee crisis is mistrust and rejection of the relocation quotas, the accounting solution contested even in the heart of Europe, in Strasbourg the dominant feeling is concern about the inability of the political leadership to manage the crises that Europe faces Although the European Union is at the world decisive economic forefront thanks to the size of the European economy, how they manage the refugee crisis diminishes its credibility and forces it to undertake a longterm foreign policy strategy in the sphere of migration and asylum.[7]

The paper is based on two pillars, which provide an overview of the conceptual and practical aspects of the two recent phenomena in the European history - the manner in which the post-Lisbon Europe ensures the welfare of the populations present on the old continent through economic diplomacy, and how the refugee crisis debuts in 2015 was managed in the perspective of the dangerous cleavage between the East and the West.

The scientific methodology is based on a literature review (primary and secondary sources) to scientifically place the European economic diplomacy in the global context, mainly based on qualitative data, complemented by statistics from the official websites of the European institutions or bodies specialized in migration, asylum and refugees. However, the research methodology is interdisciplinary and mixed (both qualitative and quantitative), using a bibliography based mainly on primary sources, but also on academic research resources and think tanks recognized in the transatlantic environment. The qualitative methodology has analyzed the main definitions, classifications and theories identified in special literary works, academic papers and previous studies in order to get a clear view of the phenomena. We do not 
intend to present an exhaustive study, the subject of European Union's economic diplomacy correlated with the refugee crisis remains open to new perspectives, especially in the context of the continuous updating of information.

\section{The Role of EU Economic Diplomacy in the global context}

In a very simplistic way, the economic diplomacy has as main focus the economic issues of a state. More broadly, it is a foreign policy function that reconciles foreign policy efforts with the need for the economic welfare of the citizens. Economic diplomacy is a complex process that brings together the representing of the economic interests of a state or supra-state entity with the adoption of appropriate economic decisions that could contribute to the development of the economic welfare of the population in that specific state. Economic diplomacy uses a wide range of tools, from simple informal negotiation to voluntary cooperation via codes of conduct or other internal rules.[4]

A feature of economic diplomacy is its enhanced sensitivity in economic markets, something which political diplomacy does not consider a priority. In this context, it is important to underline that there is no economic diplomacy theory to predict how states, in certain circumstances, will build and implement their economic policies designed to ensure the welfare of the population. The European Union is a soft power, and the European economy is one of its most important pillars of action. The economy has become a major field of diplomatic actions of the EU member states and an important milestone in managing the crisis that the European space faces. In this regard, the refugee crisis, although it should have been an economic opportunity for the European Union, has shown that the post Lisbon Europe continues to be a supranational entity marked by poor health. [8]

The turbulent political and economic context of the year 2015 - the Eurozone crisis, the terrorist attacks in Paris, the Syrian refugees' crisis, extremism and populist movements such as National Front or UKIP, the potential Grexit and Brexit, the relationship with Putin's Moscow - have underlined once more that the Union is a normative power, divided into two Europes: the West and the East, acting more diplomatically and economically than politically and military.[13] The international sanctions imposed after Russia's annexation of Crimea, Greece's financial aid, the humanitarian aid given to the refugees are evidence that the economic diplomacy of the European Union increasingly serves as a tool for negotiating safety conditions at an European level and as a mechanism to ensure a decent standard of living for the indigenous European population or the refugees who recently entered the territory of the old continent.

Generally, economic diplomacy represents the decision-making and negotiation process in international economic relations. It is more about a process than about the state structure or power or a universe of negotiation. At a European level the European economic diplomacy includes the same decision process translated into how the Member States and the central level (Brussels) succeeded or not in having a common position in negotiations, a position that the European Union must defend in its negotiations with third parties [8]

European economic diplomacy can not be reduced to simple economic actions taken by diplomats or simple trade relations in the foreign policy plan. European economic diplomacy has great importance for the European project due to multiple reasons. First of all, the international economic relations have been for several years in a multipolar logic, the European Union's economic diplomacy is thus important from a purely systemic point of view. Moreover, this form of diplomacy shows the Union's ability to bind solid economic relations with other countries in terms of foreign trade, investment, monetary relations or financial flows. Secondly, the European economic diplomacy places the Union in the worldwide economic decision-making sphere. Let us not 
forget that the European Union, although many deny this, remains an important decision-maker in the international economic area, especially considering the fact that it operates as a single market with 28 member states, which comprises approximately $20 \%$ of the international trade [25]. Moreover, European economic diplomacy is of great interest, since it must align the internal European economic policy elements with the European foreign policy ones. Finally, the European Union can, through its economic diplomacy, provide co-leadership in international economic problems ensuring the stability of the international economic system.

If we ask what are the mechanisms through which the post - Lisbon European Union is exercising economic diplomacy, we can start by saying that this innovative giant construction has a population of over 500 million Europeans, the third largest after China and India, and a stretch of 4,324,782 $\mathrm{km}^{2}$, performed most of world trade and generates one third of the human welfare, while being the largest provider of financial assistance and advice to developing countries [8]. With an international legal personality, the European Union is involved more deeply in the prevention of international conflict, European and global peacekeeping, countering terrorism, humanitarian assistance and political asylum to refugees from war zones.

The European Union is a major actor in international economic negotiations in particular due to the size of the EU economy. In this context, the development of the Union's economic diplomacy has a systemic importance for the global economic hierarchy, but also a domestic importance for the 28 member states. However, European negotiators have a limited market power, the relative European economic power is in a slight decline compared to the emerging economic powers, such as China or India, countries with a genuine growth potential in the coming years.
The European Commission, the EU High Representative and the European External Action Service must propose as soon as possible practical strategies for the European Union's foreign policy in generating conflicts and economic hardship in the extra community space that produce a massive exodus of populations towards the prosperous West, seen as a Providence State. Moreover, the European economic diplomacy must relate with the Refugees' diplomacy [13], a new form of diplomacy (not receiving a structured framework) which refers to the national, European and international border control framework and also to the legislation on migration, which is most often exercised not by career diplomats but by ministers or commissioners interested in immigration, internal or external control.

The European Union must have an updated legislation in the year 2016 regarding protection, asylum and migration and must play a more active role as a global actor, especially in the areas where nation states are too repressive or in direct conflict with the people who seek a better life in Western Europe. What is important to remember is that in 2015 the invasion was carried out from countries with a weak education system and in which religion played a significant role in society (mostly Sunni Islam). In order to thrive, Europe needs skilled labor and well intellectually trained immigrants because, as we saw with the international mobility programs supported by the European Union, Europe will not be satisfied with a generous stream of intelligence that brings it added value. [24]

To conclude this part of the paper, we consider a good approach that the EU members declare that they only want registered immigrants, with a good level of training, immigrants that will solve both the problem of population density in the old continent as it was found that the birth rate grows only in the countries where the contribution of immigrants from different generations through families with children, is significant [2]. The costs will be huge and,

Anca Gabriela Ilie and Dan Dumitriu (2017), Journal of Eastern Europe Research in Business and Economics, DOI:10.5171/2017.562051 
unfortunately, will add to other European government mistakes.

\section{Understanding the migration challenges on European Union Economic Diplomacy and the EU Responses}

The immigrants' crisis, a crisis unprecedented in the history of the European construction, short-circuited the European project with a series of consequences in the short, medium and long term. It is a crisis linked more to the common European values and not necessarily to the management of the massive influx of immigrants towards the old Continent.

\section{Deficient Regulations Regarding Asylum}

Angela Merkel declared that the massive flow of refugees that Europe is facing is a more important test than even the financial collapse of Greece. This statement has a foundation linked to the un-adapted mechanisms that the EU has to handle this crisis. First, there is no standard at the EU level to regulate the issue of asylum, a common list of countries considered to be in conflict, resulting in more refugees and no collective centers to house asylum seekers and to provide them with food. Thus, the main problem was a low adaptability of the Union's judicial framework regarding asylum and migration [9]. In other words, the European Union is likely to create dissension within itself in an attempt to effectively manage this situation.

\section{Smuggling}

One of the most important threats to the European Union's refugee crisis is the trafficking of migrants. This category of organized crime refers to facilitating border crossing illegally in another state for the purpose of profit. Transnational organized crime groups tend to act in this segment because the profits are substantial and the risks of being detected are low. In this sense, the groups operate in a more organised manner and create professional networks that transcend state borders. For these criminal groups, the migrant is just a product, along with drugs or weapons, which guarantee them material benefits [21]. The desire of obtaining asylum in the European states augmented an illicit market for the transfer of migrants, in which the traffickers are migrants themselves and use their knowledge to transfer others in exchange for compensation. There are also cases in which the migrants arrived in the EU through this system, integrate further into the criminal grouping, creating a transnational network much stronger and more damaging to the $\mathrm{EU}[21]$.

\section{Terrorism}

Philip Breedlove, commander of the NATO forces in Europe said that ISIS terrorists infiltrate Europe via refugees: "The Islamic State is spreading like a cancer among the refugees" [29]. He also noted that several European countries have signaled that they have information aimed at preparing terrorist attacks on their territory. Moreover, Breedlove launches a serious allegation against Russia's Vladimir Putin, who is said to use, with the regime of Bashar al-Assad , the phenomenon created by the refugee crisis in order to overwhelm the European structures [29].

\section{The danger of destabilizing the European Union}

This threat was highlighted by French Prime Minister Manuel Valls, who claimed earlier this year that, mistakenly managed, the refugee crisis threatens the idea of the Union. Thus, he argues that we need a much stronger control of the Union's borders and that, at the same time, we have to change the message sent by Germany, that it will provide asylum to all who request it. The French Prime Minister like the idea that Germany should be helped in its brave attempt to manage the crisis, but supports the need to send a strong message, expressing that not all refugees will be welcomed in Europe. To the contrary, this call which supports granting all those seeking asylum refugee 
status creates major risks and challenges unprecedented in the European Union [17].

\section{Attacks carried out by groups of refugees against European citizens}

Since the beginning of the crisis to date, many cases of harassment and attacks were presented in the international media. For example, Telegraph.co.uk presented in February this year how two retired Germans were attacked in the subway because they tried to protect a woman who did not answer advances from refugees.[10].

The whole situation was created ever since last year, when there were the first cases of harassment in Germany, but it is not the only European country that has faced attacks from refugees. Most cases occurred in Germany (multiple sexual assaults and harassment in five cities), Switzerland (six women were attacked in Zurich in the New Year's Eve), Austria (attacks by delinquent groups of masked refugees), Sweden ( a woman was attacked and robbed). In these circumstances, early this year, authorities have advised women to avoid travelling alone on the street at night, according to the publication Dailymail UK [23].
The wave of migration to the EU includes not only war refugees from Syria, Iraq and other conflict zones, but also other types of migration, which is usually neglected by the press and the emotional public opinion. But this distinction is important in order to provide a consistent approach common European policies and a better understanding of the phenomenon [26]. This research tried to capture opportunities and the level of state involvement of Romania in the management implications refugee crisis. Is Romania prepared to successfully implement integration policy for refugees? Would Romanian society be able to get over stereotypes and prejudices in favor of a European democratic spirit? All these questions will guide this study, in order to determine whether the Romanian state is willing and able to assume international obligations in the context of the refugee crisis in Europe. In early autumn of 2015, the entire EU is faced with a unique situation for her as an entity (massive exodus in waves of populations to Europe), but also as a political construction designed to protect, promote European identity in the $21^{\text {st }}$ century, therefore, designed to provide security, stability, prosperity to the people of states that joined the EU as full Member States.

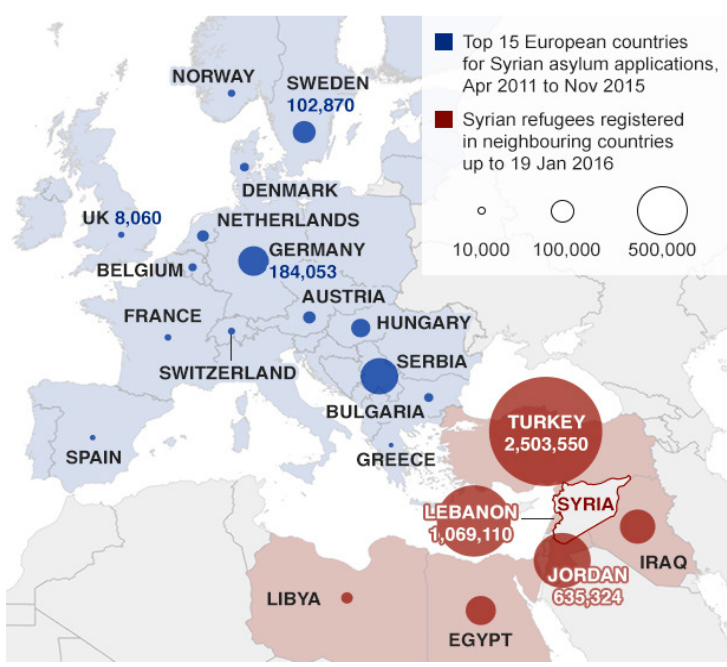

Figure 1: The main routes of migration from Middle East and Africa to Europe (2015)

Anca Gabriela Ilie and Dan Dumitriu (2017), Journal of Eastern Europe Research in Business and Economics, DOI:10.5171/2017.562051 
Source: EUROPOL apud Lewis Dean. (2015). „Revealed: Dangerous routes African migrants use to reach UK", http://www.ibtimes.co.uk/revealed-dangerous-routes-african-migrants-use-reach-uk1492672.

This wave of immigrants practically forced entry into the EU in a sudden, massive, desperate way, bringing a phenomenon of mass migration or an exodus of populations from outside Europe that "besiege Europe" is the result of relaxed policies, if not even ignorance or lack of interest by the Commission and the Western countries especially the Union to the EU countries from the southern border of the Union (Greece, Italy, in particular) which for years were faced with the phenomena of having their borders forced by non-European citizens (the phenomena of illegal immigration and phenomena related to organized trafficking in

[3].

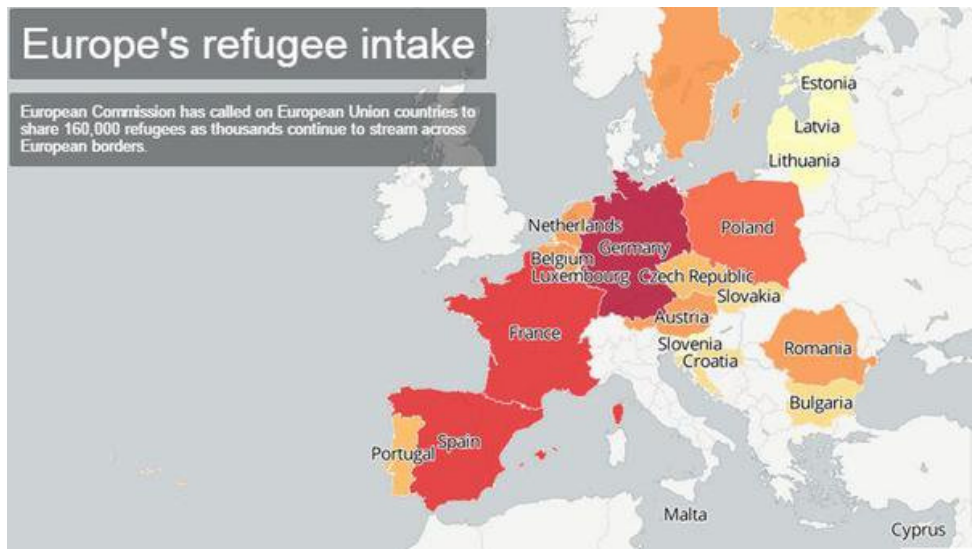

Figure 2: Top European Countries for Syrian refugees (2015)

Source : Al Jazeera, Interactive: Europe's Refugee Intake - how many refugees should each EU country take in?, https://twitter.com/ajenglish/status/642041872433717248

According to "The European Response to the Syrian Refugee crisis, What Next ?", 9 out of 10 refugees choose to go in the mostdeveloped and Antonio Gutteres, former UN High Commissioner for Refugees, said that the best way to fight against people who want to bring instability, traffickers and terrorists, is finding the best legal solutions to welcome refugees [30]. This surprising lack of strategic thinking in the EU diplomacy was the result of a lack of clear strategy, coherent of the Union for areas such as the Mediterranean countries the source of the phenomenon of migration due to military conflicts and under-developed countries in other regions of the world. It was considered quite shallow and unacceptable for the EU that was assumed by the Lisbon Treaty as a global player, that the southern EU borders can manage alone, without a specific strategy of the EU risks of illegal migration, on grounds of persecution because of war or economic considerations, risks to security, stability and identity European Union alone [3]. Every decision and action affecting full EU internal and external policies of its Member States and national political leaders are obliged to put their states and obligations they have assumed under international treaties. In addition, not all decisions by EU and its institutions are well-received nationally, especially when they involve major economic, political and social changes [3].

Anca Gabriela Ilie and Dan Dumitriu (2017), Journal of Eastern Europe Research in Business and Economics, DOI:10.5171/2017.562051 


\section{Romania's position on refugee crisis}

Romania has a very good image in Arab countries in Islamic areas generally, traditional relations and lasting friendship that could be used in the second stage, identification of solution depth, real, constructive for the EU to stop at source conflicts generating massive exodus, this image can not be jeopardized by the inability and lack of solutions to the Western countries in the EU [3].

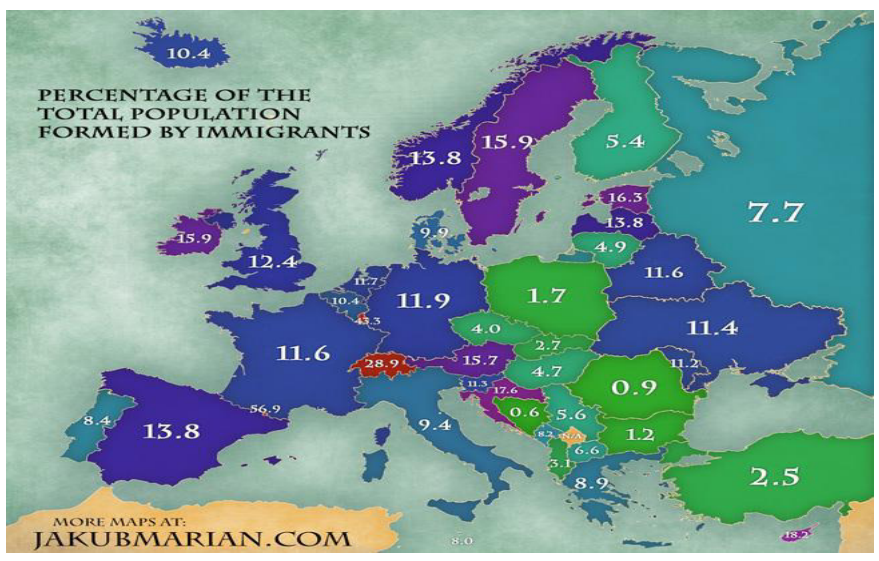

Figure 3 : Immigration in Europe, 2015

Source: ONU Report 2015

http://www.un.org/en/development/desa/population/migration/data/estimates2/estimatestotal .shtml,

In May 2015, the refugee crisis and the challenges posed to certain European countries such as Greece and Italy, the EU adopted the European Agenda for Migration, the resulting obligations for all Member States. European Commission initiated under this Agenda two packages to implementing resettlement of migrants in the $\mathrm{EU}$ by compulsory quota allocation method refugees for each Member State [24]. Thus, in early September 2015, the European Commission expect that Romania can receive a total of 6351 refugees [24].

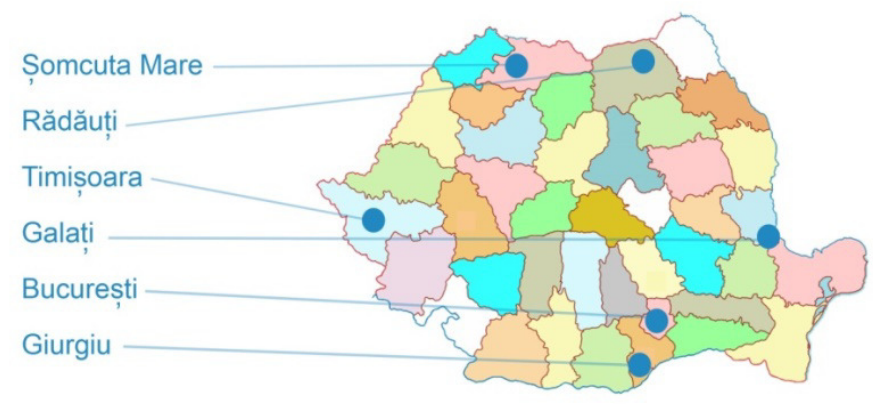

Figure 4: Romania - Shelters for Refugees

Anca Gabriela Ilie and Dan Dumitriu (2017), Journal of Eastern Europe Research in Business and Economics, DOI:10.5171/2017.562051 
Source: http://www.aidrom.ro/proiecte/asistenta-solicitanti-de-azil/, accessed on 12.03.2017

According to the National Immigration Strategy for the period 2015-2018, Romania was initially allocated a quota of 2362 people, including 1,705 through the emergency mechanism and 657 persons by non-EU resettlement program. The Romanian government approved it, but only July $2^{\text {nd }}, 2015$ Memorandum on the implementation of European Council conclusions, which agree to receive urgently a number of 1,705 people and only 80 people through the mechanism of relocation non-EU [28] . In addition, the Romanian President was opposed the Commission to receive 6,000 refugees share what had been originally distributed Romanian state, saying that Romania has the capacity to accommodate only 1,785 people [27]. Despite appeals, the decision of the Justice and Home Affairs Council was sufficiently clear so that Romania will be given the number of refugees distributed through the mechanism of mandatory quotas. As the official position of Romania in Brussels that disappointed Romanian analysts and surprised negatively European community, the Romanian state withdrawing itself from the core of the EU by its flexible position on the number of refugees it can receive. Romania became the "bone of contention" on refugee "mandatory quota", rasing the question "is solidarity voluntary or mandatory?" [14] Romania Received on March 3rd 2016 its first 15 refugees that are going to stay in Galati the Refugee Center. It is a small number Currently That corresponds with the available housing capacity of approx. 1500 places [14].

Table 1: Romania's Refugee Centers and their housing capacity

\begin{tabular}{|l|c|}
\hline \multicolumn{1}{|c|}{ Refugee centers } & Number of places \\
\hline Bucharest & 470 \\
\hline Galați & 300 \\
\hline Giurgiu & 200 \\
\hline Rădăuți & 180 \\
\hline Șomcuța Mare & 250 \\
\hline Timișoara & 100 \\
\hline
\end{tabular}

Source: Sebe,M. (2015) , Romania stance in the Issue of Refugees Crises, Institute of European Democrats, 2016, Bucharest, https://www.iedonline.eu/download/2016/IED-Mihai-SebeWorking-Paper-2016-update.pdf

At the moment, Romania is the European country with the lowest rate of immigration in the EU $(0.9 \%)$. Romania grants extremely small financial allowance to asylum seekers and provides protection as a refugee to a small number of applicants. In 2014 Romania has registered 1506 applications for asylum; 713 received some form of protection or refugee status. Between January $1^{\text {st }}$ and May $31^{\text {st }}, 2015$, Romania registered 719 asylum applications (343 from Syria, 120 from Iraq and 21 from Ukraine) [15]. During 19912013 Romania received 25100 applications for asylum and granted some form of protection for 5200 persons. Thus, Romania has no reason to fear that it will be overrun by refugees and could have a more nuanced position on quota refugees. Romania's position so far has been to reject the imposition of quota refugees and retains the option of accepting voluntary quotas. Romania did not know yet and does not know how to manage this. [15]

Along with Romania, also Hungary, the Czech Republic and Slovakia, opposed European decisions on refugees, voting against mandatory quotas. Reactions of EU member 
states regarding crisis management refugees were different and arose political tensions in Europe. Although during the Second World War, hundreds of thousands of Europeans were deported and forced to seek refuge outside their home states to survive sympathy towards refugees has resonated in the minds of all European states. Thus, in European Union were created the opposite sides on refugee crisis being questioned idea of vision on European principles and values assumed. Germany, for example, not only was the main destination chosen by the refugees, but was among the few European countries that have offered to host large numbers of refugees. Unlike Germany, Hungary and the Czech Republic preferred to remain transit countries and proved to be less welcoming regarding refugees. This crisis can create vulnerabilities of migrants and loophole for foreign terrorists combatants returning home easier in states or DAESH fighters, al-Qaeda, etc. which can infiltrate into Europe. However, Member States fear that migrants arriving in Europe can accommodate about the visions of sovereignty and militants DAESH can plan, finance, promote or incite terrorist acts on the territory of European states [12].

The reactions of Romanian officials about the refugee crisis were marked by a series of diplomatic mistakes that surely will remain embedded in the history of Romanian EuroAtlantic state. Without arguments or real concern, Romanian officials hasty in giving official statements, instead strengthen Romania's position on the international stage, have degraded the image of the state and its institutions in Europe. This crisis had also a similar effect on the Romanian political landscape as it made us reevaluate our own values and ideals and have exposed our fears as well as dreams. We have assisted to the increase of the lack of confidence of citizens in the state and European institutions given the sometimes more than chaotic approach of the refugee crisis and there are fears that this could favor the anti-European political parties and movements. This is obvious if we take into consideration the dramatic increase of the percentage of Romanians who are against receiving refugees in Romania: from $52.6 \%$ in September 2015 to more than 75.8\% in December 2015 [15].

During time, cooperation states in international institutions have proved to be mutually beneficial, especially in crisis situations. Throughout history, Romania has relied on the continuous support of the international community and fought for more than a decade to be accepted at the negotiating table with the most influential states. However, in 2015, Romanian leaders have made a series of mistakes that have affected and are likely to affect the further bargaining power of the Romanian state in the EU, because it left the impression of a limited, selfish and insecure state.

In our opinion, the attitude of Romania on the acceptance quota of refugees was flawed politically and diplomatically. The Romanian state and its leaders must learn to share, not just to receive. In this sense, Romania must share responsibilities, resources, capabilities and solutions along with its partners, because in turn they received help when needed or when asked. General opinion discusses the values of solidarity and tolerance and finds that Europe is in a stage of multiple crises as a result of its policy of openness, but also as a result of political errors that were made along the European integration. On the other hand, it is said that it is a phenomenon that is more about quality of each individual seen in particularity, together with the need of integration, rather than quantity, so the solution carrying the EU allocation refugees according to a purely accounting algorithm is challenged in eurometropola.

Also Romanians' perception of this refugee crisis shouldn't be neglected, the acceptance and attitude towards refugees, which helps us to analyze in detail the measures to be proposed for its management and its implications for foreign policy and Romanian diplomacy. It should be emphasized that 
future research topic is the analysis of authors.

\section{Conclusions}

The European Union has reached a point where it can hardly see the future if it does not adopt a series of strategies to fight the crisis, strategies validated by all the Member States of the European project. In the context of this migration crisi, Europe should consider appropriate integration policies options, taking into account models that work and avoiding failures so far.

The Refugee crisis must be understood in a wider geopolitical context redefining the European Union's role on the world hierarchy, but with caution given by the fact that the immigrants bring with them some of the difficulties from the area they come from and prove more often that their behavior is deeply anti-Western, where jobs are selfexplanatory as well as the access to women (the events of New Year's Eve from several German cities). Moreover, the open arms policy led by Europe in the early onset of this wave of immigrants leads to a deep dissatisfaction from the Europeans, which is reflected in the growing popularity of extremist parties (France, Germany, Great Britain). And the political errors coming from the European and national leaders further broaden the electoral spectrum of the extreme right in Europe.

And although the idea circulated among the public that Germany supports immigrants / refugees / invaders even though it faces demographic problems, the refugee crisis is not a phenomenon of demographic nature (even though most immigrants are young men) but one of cultural and civilizational nature announcing a cold shower for common European values launched by the founding fathers of the European Union and the European project cemented in history. The wave of immigrants brings in Europe an ideological crisis of the European mechanism, a split between the tolerant and solitary West and the fearful and closed East.
However, both the East and the West admit that the threat represented by the wave of immigrants is real and is growing rapidly, and regards not only the assault on Europe as such, but as an applied electric shock to stability, peace and prosperity on the old continent.

Europe's big challenge is thus to find a common livelihood in the uncertain future of the European Union. A wave of replacement of the European Christian population is forseen with population connected to Islam in a context in which the answers of the West against Islam were so far largely military (although hesitant), economic (economic sanctions) or anti-cultural (satire- Charlie Hebdo type). Still no measures have been taken for another interaction with Islam: converting young Europeans to Islam in a forced or voluntary form. Moreover, European solidarity must be managed which has been neglected in the past year. We refer here to the fact that the border states of Europe were always singled out because they can not grow and prosper economically and the refugee crisis has proved that the rich West can not withstand the crisis that hit Europe without the periphery of the Union.

The current European wave has economic, ideological, cultural reasons but is generated largely by the political errors of the European leaders in the area of foreign policy and westernisation of other regions (especially the conflictual ones) in the world. Therefore, what is needed is a repositioning of the European economic diplomacy in the adoption of concrete strategies of foreign policy of the European Union in generating conflict and economic problems in areas that produce massive exodus of population, attracted by the Providence state in the West. Although it is difficult to predict, it may be the beginning of the end of the European Union if the diplomatic elite, along with commissioners from the area of trade, migration, external control, fail to give a new impulse to the immigration policies already set by the Lisbon Treaty. 
A humanitarian response to the refugee crisis and coordinated action to distinguish on the basis of international and European law, between refugees and other migrants - the situation would have been different and could avoid tensions. Many of these actions show that the emphasis is on identifying the causes of migration and solving them at source. International coalition intervention in Syria is part of this new plan to eradicate as much as possible the cause of actual migration and an extremely dangerous hybrid terrorism, which is fed from extremist ideology. [15]

\section{Notes}

This article is a continuation of research "European Economic Diplomacy and the Refugees' Crisis" author Anca Gabriela Ilie, published in Cross border Journal of International Studies no 1/2016, Dunarea de Jos University, Galati, where the author is also part of the Editorial Board

DAECH: The self-proclaimed Islamic State appeared in the summer of 2014, on June 28, the first day of Ramadan, when terrorist Abu Bakr al-Baghdadi was proclaimed caliph of the new Islamic state in the territories conquered by jihadists. Originally it was called the Islamic State of Iraq and Levant (ISIL), then the Islamic State of Iraq and Syria (ISIS), then the Islamic State and Daesh. Title which was initially required in the literature was ISIS.

\section{References}

1. Aligicã, D., (2016), In aşteptarea unei strategii europene in Sorin Bocancea (coord.), Marşul asupra Europei. Noile dimensiuni ale migraţiei, Editura Adenium;

2. Antohi, S., (2016), "Dystopia europaea" in Sorin Bocancea (coord.), Marşul asupra Europei. Noile dimensiuni ale migrației, Editura Adenium;

3. Antonescu, M.V, (2015), "Poziția României în problema crizei imigranților: câteva comentarii", Policy paper 18/ 2015, Institutul Diplomatic Român, Bucharest
4. Bayne, N., Woolcock, S., (2011), What is economic diplomacy in Stephen Woolcock, in Nicolas Bayne and Stephen Woolcock, The new economic diplomacy. Decision-making and negotiation in international economic relations, The London School of Economics and Political Science;

5. Chavagneux, C., (1999), La diplomatie économique, plus seulement une affaire d'États in Pouvoirs. Revue française d'études constitutionnelles et politiques, nr. 88;

6. Cincea, M., (2016), "Va reuși Europa sã iasã din capcanã" in Sorin Bocancea (coord.), Marşul asupra Europei. Noile dimensiuni ale migraţiei, Editura Adenium;

7. Chifu, I., (2016), Dosarul imigranților. Cine sunt, de unde vin, cum gestionãm aceastã temã in Sorin Bocancea (coord.), Marşul asupra Europei. Noile dimensiuni ale migraţiei, Editura Adenium;

8. Crãciunescu, A., Silasi, G., Anghel, I. M., (2015), Diplomaţia Uniunii Europene şi regulile acesteia, Editura Universul Juridic, 2015, p. 580.

9. Erlanger, S., Male, A., Europe's Halting Response to Migrant Crisis Draws Criticism as Toll Mounts, The New York Times, 2015, disponibil la: http://www.nytimes.com/2015/08/29/wo rld/europe/europe-migrant-refugeecrisis.html?smid=fb-share\&_r $=0$

10. Hall, M., Kroll, M., German pensioners 'attacked by migrants after defending young woman", Telegraph.co.uk, Berlin, 2016, http://www.telegraph.co.uk/news/worldne ws/europe/germany/12135497/Migrantsattack-pensioners-who-stood-up-forwoman-they-were-harassing-on-Munichmetro.html 
11. Ilie, A.G. (2016), European Economic Diplomacy and the Refugees' Crisis, Cross border Journal of International Studies no 1/2016, Dunarea de Jos University, Galati

12. Kaplan, M. (2015). „Refugee Crisis: ISIS Fighters In Europe? Islamic State Extremists Exploit Refugee Flow, Waiting To Launch Attacks, Militant Operative Says", International Business Times, 7 septembrie, http://www.ibtimes.com/refugee-crisisisis-fighters-europe-islamic-stateextremists-exploit-refugee-flow-2085787.

13. Maley, W., (2013), Refugee Diplomacy in Cooper A., Heine J., Thakur R., The Oxford Handbook of Modern Diplomacy, Oxford Handbooks Online

14. Sebe,M. (2015), Romania stance in the Issue of Refugees Crises, Institute of European Democrats, 2016, Bucharest, https://www.iedonline.eu/download/2016 /IED-Mihai-Sebe-Working-Paper-2016update.pdf

15. Soare,S. Postelnicu,C. (2016), Impactul noilor măsuri de combatere a fenomenului terorist, propuse la nivel European asupra liberei circulații, Studii de Strategii și Politici SPOS nr 5, Insstitutul European din România, Bucharest

16. Tompea, D., (2016), Criza europeanã a imigranților. Radiografia unei drame colective in Sorin Bocancea (coord.), Marşul asupra Europei. Noile dimensiuni ale migraţiei, Editura Adenium;

17. Valls,M. (2016), Criza refugiaților amenință ideea de Uniune Europeană, Agerpress

http://www.agerpres.ro/externe/2016/01 /22/manuel-valls-criza-refugiatilorameninta-ideea-de-uniune-europeana-1211-57.

18. Vãcãrelu, M., (2016), "Invazia Europei şi consecinţele sale în secolul XXI" in Sorin Bocancea (coord.), Marş asupra Europei. Noile dimensiuni al migrației, Adenium, pp. 57-65;
19. Woolcock, S., (2012), European Union Economic Diplomacy, Ashgate Publishing;

20. Woolcock, S., (2011), European Union Economic Diplomacy in Nicolas Bayne and Stephen Woolcock, The new economic diplomacy. Decision-making and negotiation in international economic relations, The London School of Economics and Political Science.

21. UNODC (2011), Fișa crimei organizate transnaţionale. Traficul de migranti-Dura căutare pentru o viaţă mai bună,p. 1,disponibil l http://www.unodc.org/documents/toc/fact sheets/TOC12_fs_migrantsmuggling_EN_Pla in.pdf,

22. UNODC, Rolul crimei organizate în traficul de migranţi din Africa de Vest spre Uniunea Europeană, New York, p. 1, disponibil la http://www.unodc.org/documents/humantrafficking/Migrant-

Smuggling/Report_SOM_West_Africa_EU.pdf

23. Wyke, T., Akbar, J. (2016), „Migrant rape fears spread across Europe: Women told not to go out at night alone after assaults carried out in Sweden, Finland, Germany, Austria and Switzerland amid warnings gangs are co-ordinating attacks", Dailymail, 2016, disponibil la: http://www.dailymail.co.uk/news/article3390168/Migrant-rape-fears-spreadEurope-Women-told-not-night-assaultscarried-Sweden-Finland-Germany-AustriaSwitzerland-amid-warnings-gangsordinating-attacks.html

24. European Commission, Fact Sheet, 22 September 2015, http://europa.eu/rapid/pressrelease_MEMO-15- 5698_en.htm, accessed on 05.03.2017. 
25. Europa.eu, http://europa.eu/abouteu/facts-figures/economy/index_ro.htm, 2016.

26. Expert Forum (EFOR), (2015), "România și criza migrației", Policy Brief no.39, octombrie 2015, http://www.contributors.ro/wp-

content/uploads/2015/10/Pol-Brief-39.pdf

27. International Business Times, Romania Refugee Crisis Update: Previously Opposed To Quota, Prime Minister Says Country Could Take More AsylumSeekers,update-previously-opposed-quotaprime-minister-says-country-2127424, accessed on 06.03.2017.

28. Strategia Nationala privind migratia, 2015-2018, pp. $2-3$, http://www.mai.gov.ro/documente/transp arenta/Anexa $\% 201 \% 20$ Proiect $\% 20$ HG\%20 strategie\%20imigratie $\% 20$ si

$\% 20$ plan\%20actiune.pdf,

29. TV News - Philip Breedlove, commander of the NATO forces in Europe, Criza refugiatilor, arma pentru teroristi si pentru Rusia. "ISIS se raspandeste ca un cancer",

http://stirileprotv.ro/stiri/stirileprotvspecial/seful-fortelor-nato-in-europa-crizarefugiatilor-arma-pentru-teroristi-sipentru-rusia-isis-se-raspandeste-ca-uncancer.html

30. Robert Shuman Centre for Advanced Studies,(2014), The European Response to the Syrian Refugee crisis, What Next ?, MPC Research Report 2014/14, European University Institute, http://www.migrationpolicycentre.eu/docs /MPC\%202012\%2014 